\title{
CHANGES IN EMPLOYMENT SECURITY IN ASIA
}

Adam Lee and Sarosh Kuruvilla

Cornell University

February, 2001

Acknowledgements

We thank Samuel Bacharach, Bill Sonnenstuhl and other participants at the conference on the Changing Social Contract held at Ben-Gurion University, Israel, May 2000. 


\begin{abstract}
Much attention has been focused on the decline of traditional employment structures in the advanced industrial countries. Lesser attention has focused on this issue in Asia. In this comparative essay, we examine the changes in employment security in China, India, Japan, and South Korea. We focus on the historical development of the employment security social contract in these countries, noting the institutional features that gave rise to it in each country. We then examine the resilience of employment security norms under recent economic pressures. We find there has been substantial erosion in employment security during the 1990s in all four countries due to both increased competition and economic liberalization, although there is some variation in both the rate of erosion as well as the prospects for revival of the social contract. We assess the possibilities of a revival in this particular social contract, and the impact of the erosion on unorganized workers.
\end{abstract}




\section{Introduction}

Dramatic changes in employment relations systems have taken place in the 1990s in most countries (Katz, 1993, Kuruvilla and Erickson, 2000). Of the many changes in employment relations systems (e.g., bargaining structures, union declines, externalization of production), one development that has attracted a large amount of popular attention is the change in the structure of employment. In almost every nation, the proportion of people who have full-time permanent employment has been decreasing, while part-time, temporary and contingent employment has been on the increase. This decline in "secure" employment is a viewed by social critics and particularly critics of globalization (seen by them as a driving force in these changes) as a breakdown in the "social contract" and there have been numerous calls for both legislative and institutional intervention (particularly from labor unions, but also other groups in civil society) to prevent further erosion in employment security.

In this article, we focus on the decline of secure employment in Asia. We focus particularly on Japan and Korea (Asia's industrial leaders), and China and India (the two largest nations who have only recently liberalized their economies). All of these nations have also experienced considerable declines in employment security. For instance, whereas the Chinese Communist Party spoke frequently about workers all “eating out of one big pot”, Chinese State Owned Enterprises have retrenched 20 million workers over the last two years (O'Leary, 1998). Despite Indian constitutional provisions that the state "shall endeavour to secure” work for all workers, the Indian government is now exerting considerable pressure on public sector employees to retire “voluntarily”(Markandan, 1996). Unlike in China and India, in Japan it is private sector workers whose employment security is under threat. Even large Japanese corporations, famous world-wide for their life-time employment practices, seem to now be moving toward less secure employment relationships, a direction that is true as well of large Korean conglomerates (Chaebol) as well (Kuruvilla and Erickson, 2000).

The departure from a high degree of employment security has been met with varied responses. In India, for example, very few public sector employees have volunteered to retire. And Korean workers, long known for their militance in the face of authoritarianism, now strike in response to employers plans to retrench. In Japan also there is public concern regarding the scale of layoffs (particularly white collar layoffs), while there is considerable public unease 
about the growing inequalities in China. These reactions are similar to those found in the advanced industrial countries, especially those with strong trade union movements who are exerting considerable efforts to preserve this "social contract". There is considerable public support for the efforts of the trade unions, particularly in Western Europe and Scandinavia, where the norm of all citizens having a secure job was fairly well developed after the Second World War.

The focus of this comparative essay is to examine the historical development of the norm of employment security (specifically to understand the conditions that gave rise to it). We examine the scope of this norm, and how that scope has changed in recent years due to economic and other pressures. We also examine how resilient this norm is, and the national and workplace institutions that contribute to resilience in each of the four nations. We conclude with our provisional assessment of the future prospects regarding employment security, and the significance of this norm for unorganized workers (a much larger proportion of the population) in each country.

\section{Social Contract and Employment Security}

Social Contract is a concept from political philosophy that dates back to Plato, (Lacey, 1996). Social contracts help to legitimate power relations.(Blackburn, 1994), and generally focus on the relationship between individuals and other individuals in states. In the sphere of political science they are often seen as agreements among individuals so that the terms of social contracts must be terms that every individual can accept.(Gaus, 1999) Rawls claims that social contracts are predicated on the notion of “justice as fairness” (Gaus, 1999) However, Sened argues that social contracts are not based on principles of justice but are rather "institutional remedies to social dilemmas.”(Sened, 1997: 12) Sened claims that social contracts “evolve” in response to changes in the dilemmas that social actors face.(Sened, 1997: 12) In other words, governments and other powerful actors in society attempt to resolve these dilemmas as well as alter social contracts in order to advance their own interests(Sened, 1997).

In the industrial relations literature, social contracts have been used to describe a large number of employment relations interactions. The term has been used, for instance to describe highly centralized bargaining systems in heavily unionized Scandinavian countries, to describe tripartite arrangements in several other countries (e.g., Singapore), as well as to describe 
workplace and firm level practices common to all workplaces. As such, employer paid benefits are seen as part of the social contract of employment, and more recently, employment security has been viewed as a social contract. We understand employment-security norms in China, India, Japan, and Korea as the subject of a social contract that provides some legitimacy to employment relationships. Although in some cases these norms have been codified into law or collective bargaining agreements, in others they have been more implicit but nonetheless powerful. Sened's characterization of social contracts meshes fairly well with our cases. Consistent with Sened, we discuss how employment security norms were shaped by complex interactions among employers, employees, and governments in response to social dilemmas. We also underscore how these norms have evolved and been "rewritten" by powerful social actors over time.

In the cases we examine (and in most countries), only certain employers (large private firms or government enterprises) and only certain employees (the core, unionized labor force of large private firms or government enterprises) have been in an employment relationship where there is clearly a norm of employment security. However, this norm has had ramifications that extend throughout the society and economy and thus affect even citizens who have not been directly protected by employment security norms. For example, the lifetime employment system in Japan has been associated with a substantial labor market segmentation and a lack of job mobility. Because these lifetime jobs in big corporations are so prized (only 30\% of Japanese workers get these jobs), most families aspire to these jobs for their children. This, in turn, puts considerable pressure on the children to do well at school, and thus, on schools to ensure that children are well educated. This translates into much higher school workloads for children at a very young age. This affects the employment pattern of women.....they prefer part time employment so that they can supervise their children's education, including after school tuition. One consequence is that women almost never break through the corporate "glass ceiling". ${ }^{\text {. }}$ Further, the lifetime employment for the core unionized workers is sustained to some degree by the prevalence of subcontracting practices where workers in the lower subcontracting tiers work in less than ideal conditions and without labor union protection. Similar pressures are apparent in Korea (where jobs with the big corporations, the chaebol, are equally prized). In China, where the state owned companies have until recently guaranteed through the "iron rice bowl" system,

\footnotetext{
${ }^{1}$ This is just one example of how employment security norms can have elaborate social effects that extend beyond the firm and are not simply economic.
} 
employment security as well as employment for one's children, the implicit social contract affects the education behaviors of an entire generation. The scarce job opportunities in India, coupled with its large population and the social contract of employment security in both government and in the private sector (backed by legislation), also puts considerable pressure on children at a young age to obtain these coveted jobs, with similar social effects. Thus when this apparently stable system changes, its ripple effects are likely to be widespread.

Apart from society, secure employment also has important ramifications for employment relations and productivity at the level of the firm. On the one hand, neo-classical economists argue that employment security norms constitute some degree of labor market inflexibility that reduces productivity and growth. On the other hand, the Japanese employment relations system, with job security as a central element in the matrix of organizational norms (Marsh 1992 and Ouchi, 1981), has been suggested as being one of the most flexible ER systems in the world. Employment security has been associated with high productivity in a large number of studies (Kochan, Katz, McKersie, 1986), and appears to be a central ingredient in getting higher skilled employees to invest in participation in decisionmaking required of high skill production systems. Thus, when this central norm changes, it is important to understand the reasons for this change

Since employment security norms have affected even citizens who have not been directly protected by them, such citizens can be seen as indirect parties to the social contract. If they are, it is not clear whether or not the terms of any social contract we examine have ever been terms that all parties to the social contract would accept. The extensive yet sometimes uncertain effects of the employment-security social contract on society and the economy make this difficult to determine. This is especially important since, in the instances we examine, only a minority of all workers were ever direct parties to the contract.

The social contracts we examine are all rooted roughly in the mid- $20^{\text {th }}$ century. Their origin is concomitant with the industrialization of these late industrializers and their existence is predicated upon specific industrialization strategies and systems of industrial organization that are time-bound. Furthermore, in some cases undermining of the employment security norm began numerous years ago. Thus, the duration of the employment security norms we examine is not great. The bounds of the employment-security norms we examine are often not clear. Regardless of whether such norms were transmitted to unorganized workers, it is clear for the 
cases we examine that employment security norms have had a large influence on at least a small fraction of employment relationships in the post-WWII era.

\section{The Development of Employment Security in China, India, Japan, and Korea}

The two subsections of this section deal separately with each of the four countries. The first subsection covers the development of the social contract concerning employment security up until the beginning of the 1990s. The second one picks up where the first one leaves off and continues to the present. In each of the subsections we examine both how pressures have threatened to undermine the social contract and how the social contract has held up under these pressures. The division between subsections at the beginning of the 1990s is somewhat arbitrary. Threats to the social contract in these countries did not suddenly emerge at the beginning of the 1990s, nor did they emerge in all four countries at the same time. However, these pressures did seem to intensify at some point in the 1990s in all four countries. ${ }^{2}$

\section{Historical Development of Social Contracts Until the Beginning of the 1990s}

\section{The case of Japan to the early 1990s}

In Japan, employment security is known as life-time employment (LTE). Although LTE is one of the "three pillars" of the Japanese system of industrial relations (LTE, seniority-based wages, enterprise unionism), like the other pillars it has never covered more than 20 -30\% of the non-agricultural workforce.(Takahashi, 1997; Rengo, 1998; Gordon, 1998) LTE originated in Japanese industry shortly before WWII but did not become widespread and established as a norm until at least the 1950s.(Gordon, 1985; Takahashi, 1997; Nakamura, 1993) Explanations for why the norm originated vary from the need to train and retain skilled employees (Takahashi, 1997) ${ }^{3}$ to government regulation aimed at decreasing turnover among industrial labor.(Gordon, 1985)

\footnotetext{
2 This accords well with recent arguments that the late 1980s and early 1990s have been a significant period of change in Asian industrial relations systems, and the intensification of globalization.(Kuruvilla and Erickson, 2000)

3 This author claims that LTE spread to blue-collar and clerical workers only after the war.
} 
After WWII, confederations of communist and left-wing social-democrat enterprise unions dominated Japan's trade union scene.(Nakamura, 1993) These unions were militant and strongly resisted mass lay-offs.(Price 1996) The unions were very prevalent in very large businesses but very infrequent in small ones, categories Japanese industry was divided into prior to and after the war.(Smitka, 1991) Until 1950, the large-business component of Japanese industry was dominated by interlocking conglomerates known as zaibatsu. Even after these were formally dissolved in 1950, the economy remained divided between very large firms and relatively small ones.(Smitka, 1991)

As output expanded rapidly during the 1950s, Japanese large firms developed a mechanism that enabled them to respond to rapid fluctuations in demand, circumvent their highly unionized, highly militant employees, and limit the expansion in the numbers of these employees. They began subcontracting en masse to smaller firms.(Nishiguchi, 1994) This practice resulted in a new kind of industrial organization in which firms divided by size were united through dense networks of subcontracting relationships.(Smitka, 1991) Also during the 1950s, the three pillars of Japanese industrial relations began to proliferate and become institutionalized in large Japanese firms.(Price, 1996) At least one of these pillars, LTE, has not protected employees in small Japanese firms.(Takahash, 1997; Gordon, 1998) Thus in the 1950s a clear distinction in employment practices between those in the large sector and those in the small sector emerged, employees in the former (internal labor markets) protected by LTE and employees in the latter (external labor markets) not protected by LTE. During this decade there was also a move away from militant to cooperative industrial relations among unionized workers in large Japanese firms, with cooperative industrial relations becoming predominant in the 1960s.(Gordon, 1998) By connecting these various developments, we see that the spread of the three pillars, including LTE, throughout Japanese large businesses is concomitant with both the moderation of unions in these large businesses as well as with the emergence of a system of industrial organization in which these larger businesses were linked through subcontracting with smaller businesses whose employees were generally not unionized and not protected by LTE.

By the latter 1960s what is known as the postwar consensus, or the triumph of cooperative industrial relations, had emerged.(Kume, 1998) This consensus was forged between moderates in both labor and business, and it took the form of a tradeoff; employees of large firms would shun work-stoppages while large firms would provide LTE and allow for wage gains to 
match productivity gains.(Gordon, 1998) Given the continuing 10\% annual rates of growth and rapid increases in productivity through the 1960s, both sides had economic incentive to forge this sort of consensus. The postwar consensus in Japan, including that component of it concerning employment security that we refer to as a social contract, was neither codified into law nor generally written into agreements between employees and firms. Instead, it was an informal norm shared by both workers and managers.(Nakamura, 1993) Conformance with this norm during the 1960s may not have been possible without the rapid growth of the 1960s.(Nakamura, 1993) The slowing of growth in latter decades tested the durability of this norm.

The Japanese economy slowed from an annual growth rate of $10 \%$ during the 1960 s to a rate of $4.5 \%$ during the 1970s.(Sako, 1997) This slowing and the unstable economic environment, resulting largely from the two oil crises, together put pressure on LTE . The 1973 oil crisis was followed by mass dismissals of Japanese workers in both internal and external labor markets. These dismissals were associated with the need to be more competitive in export markets and a widespread rationalisation of the shop-floor culminating in lean production.(Sako, 1997) Small firms resorted to outright discharge about $1 / 3$ of the time while large firms practiced voluntary severance almost exclusively (Nakamura, 1993), indicating the norm of LTE did not permeate all of society or all workplaces equally. ${ }^{4}$ While the use of voluntary severances rather than outright discharges by large firms indicates resiliency through flexibility of LTE, it also is a dilution of LTE. Although employees were compensated, voluntary severance is a means of preventing employees from working as long as they had intended to. Furthermore, some employees in large Japanese firms agreed to take a voluntary severance only after being subjected to "patting on the shoulder" and "subtle psychological pressure from colleagues”.(Nakamura, 1993, p.13) Still, voluntary severance is not the same as outright discharge. We refer to voluntary severance and other mechanisms by which employers adjust employment levels downward without resorting to outright discharge of workers protected by employment security as employment security adjustment mechanisms (ESAMs). The use of ESAMs indicates an erosion of the employment security social contract.

The shock of the 1978 oil crisis was absorbed by wage restraint and there were very few dismissals, voluntary or otherwise.(Nakamura, 1993) LTE once again proved resilient with the

\footnotetext{
${ }^{4}$ We do not argue that an employment security norm does not have some influence in small firms. The literature, however, claims that LTE has been standard only for large firms. This relates back to our discussion in the intro about the difficulty of determining the bounds of employment security norms.
} 
help of ESAMs. Transfers, early retirement, a shortened workweek (Price, 1997), and temporary and contract employment even within large firms were established as norms during the 1970s.(Takahashi, 1997) Thus, the life-span of full-fledged LTE, or LTE prior to these mechanisms of adjustment being established as norms, was only about a decade.

The 1980s was marked by another crisis that threatened LTE but also by an indication that LTE had spread beyond private-sector large companies. In 1985 the yen appreciated drastically, seriously undercutting Japan's competitiveness in export markets. The move to transferring Japanese operations overseas, which had already been underway largely due to increasing labor costs at home, was accelerated (Nakamura, 1993) and the use of ESAMs by large Japanese firms increased.(Takahashi, 1997) Voluntary retirement was widely used and, between voluntary retirement and mandated early retirement, the age at which LTE ended was effectively being reduced from 60 to between 50 and 59 for a large fraction of the segment of the workforce that was protected by it.(Takahashi, 1997) Efforts by the government during the 1980s provide evidence that the norm of employment security had spread beyond private-sector large companies. When much of the Japanese public sector was privatised during the late 1980s, not one employee was dismissed.(Sako, 1997) Employee levels were reduced through rationalisation and personnel transfer to related companies.(Sako, 1997)

Although employment security of some core employees in large Japanese firms was undermined in the 1980s, employment opportunities for other core employees increased during this decade of labor shortage. While large Japanese firms had previously hired people straight out of school, many of them began recruiting workers away from firms.(Lincoln, 1997) In response, many "life-time” employees switched employers.(Lincoln, 1997) Thus while Japanese employers had weakened employment security norms for over a decade by this time, some employees also began to undermine these norms.

\section{The case of Korea to the early 1990s}

Korean industrial relations were generally cooperative up until the late 1980s. However, this cooperation seemed to result less from any consensus between workers and their employers, as it had in Japan, than it did from a series of authoritarian "Republics" that prevented the 
development of an independent labor movement. Nonetheless, employment security has been a norm for workers in large Korean enterprises. This raises the question of why these enterprises would adopt an inflexible employment practice as the norm. An important part of the answer seems to lie in a patriarchal Korean culture and, more importantly, in the rapid and stable growth of large Korean enterprises that enabled them to conform to this culture.

The first Republic of Korea (ROK) was overthrown by student demonstrators in 1960. After a military coup toppled the second ROK in 1961 (Park and Lee, 1993), Park Chung-Hee, or General Park, led the third ROK for 18 years. In order to assert greater control over Korea, Park dissolved all existing political organizations including the recently burgeoning trade unions, formed a federation of industrial unions known as the Federation of Korean Trade Unions (FKTU), and recognized FKTU as the sole authorized labor centre.(Singh, 1997) FKTU generally did not resist the government's attempts to control organized labor in order to satisfy Park’s developmentalist aims.(Mo, 1999) Although protective labor legislation, such as the Labor Standards Act (LSA) of 1953 that makes it illegal for an employer to fire an employee without “just cause” (Kim, 1998), was generally not enforced at this time, repressive labor legislation enacted during this period served to legitimize repression of organized labor by the government.(Singh, 1997) Still, organized labor was not passive during the 1960s, and working days lost because of labor disputes increased greatly.(Singh, 1997) The Korean government responded with police and intelligence agency surveillance of the labor movement (Singh, 1997) as well as by frequently arresting and physically harming workers who disrupted business activities.(Vogel, 1997) This heavy-handed intervention in labor markets helped to enable a stable supply of cheap labor with minimal rights, which was critical to Korea's rapid economic growth in 1960s-1980s.(Park, 1993)

The Korean government's heavy-handed intervention in the economy extended beyond labor markets. Exercising almost total control over the financial system, this government both directed nationalized banks to lend to high performing companies within industries it selected for development and encouraged these companies to diversify their product lines.(Clifford, 1997) As a result a small group of large, highly diversified conglomerates (Chaebol) emerged. As Korea proceeded through a highly successful period of export-oriented industrialization in the 1960s and 1970s, the Chaebol became a dominant force in the modern sector of the Korean economy. Chaebols' sustained growth over coming decades kept pressures to retrench at a 
minimum and left them with little reason to violate Korean patriarchal norms that made retrenchment a source of embarrassment for employers.(Mitchell, 1988) The resulting Chaebol practice of not retrenching workers helped to establish employment security as the norm for Korean large businesses..$^{5}{ }^{6}$ (Lee, 2000) Despite Korea’s patriarchal culture, there has been no norm of employment security in the Korean small and medium sectors. These sectors, which in 1992 accounted for 65.8 percent of all employees in manufacturing (Mo, 1999), experienced greater business fluctuations and as a consequence developed more flexible practices of employment adjustment.(Lee, 2000) Thus, by our somewhat stylized distinction between large Korean businesses practicing employment security and small/medium Korean businesses practicing employment flexibility, this statistic suggests that around 35\% of manufacturing employees were protected by employment security in the early 1990s.

Over the course of the 1970s, an underground radical labor movement began to emerge that was independent of the officially sanctioned FKTU. This labor movement pushed for both democratization and a more egalitarian distribution of the economic gains resulting from Korea's rapid development.(Lee, 1991) Despite being repressed by the Korean government, this movement grew rapidly.(Park, 1993) Meanwhile, the Korean government privitised its public sector as part of a structural adjustment program. When it privitized, no major retrenchment occurred. ${ }^{7}$ (Park, 1993) This suggests that, like in Japan, employment security norms in Korea were not limited to large private Korean businesses.

In 1987, partly in response to a major wave of political and economic strikes, a new Korean government announced that it would decentralize political authority and allow more democratic labor organization and activism.(Mo, 1999) Labor disputes increased dramatically (Lee, 1991) and wage gains, which had already been rapid for many years, outstripped productivity gains over the next few years.(Vogel, 1997) Thus, as was the case with Japanese enterprises, Korean enterprises were no longer as competitive in domestic or export markets as they once had been and so were losing market share to later industrializers such as Thailand, Indonesia, and Malaysia. This threatened to end the period of large Korean firms’ sustained

\footnotetext{
${ }^{5}$ Because of the historically high rate of employee turnover in Korea, we do not refer to this norm as LTE. Turnover rates in Korean industry often averaged $4-5 \%$ well into the 1980s. In other words, 50 to 60 percent of a firm's workforce might change over the course of a year.(Vogel, 1997)

${ }^{6}$ We are not able to give a precise estimate for when employment security became established as a norm in Korean large businesses.
} 
growth, growth that had enabled employment security to become the norm for workers in these firms. Furthermore, the fraction of Korean workers with secure employment was decreasing toward the end of the 1980s while the fraction of the workforce with temporary or daily employment was increasing.(Korea Labor Institute, 1999). ${ }^{8}$ Reflecting this, some of the ESAMs that were widespread in Japan from the 1970s seemed to be gaining prominence in Korea at this time. Korean companies began to hire more daily workers (Park, 1993) and to contract work out under a system known as the "small president system” (Verma, 1995) ${ }^{9}$. Also, temp agencies emerged and began to spread, with the workers they employed known as dispatched workers.(Verma, 1995)

While employment security norms seemed to be under threat following Korea's rapid democratization that began in 1987, in a number of ways democratization may have bolstered these norms. The government, now subject to more pressure from below, began enforcing legislation concerning employment security more strictly.(Kim, 1998) Also, the LSA was revised in 1989; whereas before it was illegal for employers in enterprises with 10 or more workers to retrench without "just cause", the number was revised down to 5 in 1989.(Fields, 1989). Furthermore, the previously underground labor union movement emerged above ground to form a new labor union confederation (KCTU) in 1990.(Park, 1993) KCTU provided a more independent voice for labor than FKTU, which was still aligned with the government. Finally, a new tripartite council that included labor representation was inaugurated in 1990.(Kim, 1998) This held out the possibility that labor would gain a greater say in government and in the economy and thereby perhaps help to stave off moves toward employment flexibility. ${ }^{10}$

\section{The case of India to the early 1990s}

The origin of the norm of employment security in India has been traced back to the independence period $^{11}$, when the Indian public sector viewed employment creation and retention

\footnotetext{
${ }^{7}$ This parallels the case of privitisation in Japan. However, as we will see, this does not parallel the cases of privitisation in China and India, where the public sectors have made up larger shares of the economy.

${ }^{8}$ This trend continues.(Korea Labor Institute, 1999)

${ }^{9}$ This system had existed since the early 1920s in the mining sector. However, only in this period was it introduced in the manufacturing sector.(Verma, 1995)

${ }^{10}$ The KCTU was not yet recognized by the Korean government and so only the less independent FKTU participated in the tri-partite council at this time.

${ }^{11}$ India attained independence from Britain in 1947.
} 
as a responsibility.(SAAT, 1996) At the time it was expected that a majority of workers would soon be absorbed into the modern sector and that public sector employment norms would be adopted by the rest of the modern sector.(SAAT, 1996) The norm of employment security in India may have also originated in close ties between Indian organized labor and Indian politicians forged during the independence struggle (De Sousa, 1999), which could have influenced later government policy concerning public sector employment. Still, no Indian labor legislation of this era required employers to provide workers with employment security (Kuruvilla and Hiers, 1997), and we have found no indication in the literature that the private sector was providing employment security at this time.

India's development strategy enabled Public Sector Undertakings (PSUs), which comprise much of the public sector, to provide their employees with employment security. This strategy was based in state-led, import-substituting industrialization (ISI). India's ISI strategy included large tariff barriers, subsidies for domestic industries, the creation of oligopolistic markets by the state, and reservations of industries for either the public sector or for the private sector. This all ensured that many Indian markets were captive, non-competitive ones. Without the pressures of domestic or foreign competition, it was much easier to pay the cost of providing employment security and to pass this cost on to Indian consumers in the form of higher prices.(SAAT, 1996)

The scope of employment security was extended into the private sector through changes in labor laws during the 1970s and early 1980s. The Contract Labor Act (1970) made it more difficult to indefinitely employ workers on contract, though this act has not been uniformly enforced.(Sastry, 1991) More significantly, in 1976 the Industrial Disputes Act (IDA) was amended so that enterprises employing 300 or more workers must get government permission to close or to retrench any workers, and in 1982 this was changed to 100 or more workers.(SAAT, 1996) Unlike the Contract Labor Act, IDA has generally been better enforced. Amendments to IDA in the 1970s and 1980s ended the period in which Indian employers had total control over their employment levels. While employment security became the norm in the public sector because of the public sector's views from independence and possibly because of ties between unions and political parties, the norm was now legally mandated in both the public and private sectors. Ironically, it was only shortly after the 1982 amendment to the IDA that India began its shift away from ISI and toward export oriented industrialization (EOI) and domestic competition 
and thereby seemed to make the provision of employment security more difficult in the public and private sectors alike.

As a result of the shift toward EOI and domestic competition, Indian firms were under pressure to fire redundant labor, of which there was plenty.(SAAT, 1996) Sick Industries and Companies Act (SICA) of 1985 was another bad omen for employment security. It aimed at bringing about either restructuring or closure of poorly performing enterprises. This contradicted IDA which, in the name of employment security, effectively discouraged shutting enterprises down regardless of their performance. In coming years, this legal contradiction served as a de jure test of employment security norms' strength in India’s large public sector and private sector firms. On this de jure test, the social contract fared well. IDA continued to force sick enterprises to remain open while SICA failed to enable sick enterprises to shut down. However, since the 1980s there has been an ongoing de facto test of the employment security social contract in India. The 1980s was marked by an increase in the use of ESAMs, including subcontracting, temporary work, and contract work.(Ramaswamy, 1997; Bhattacherjee, 1999; Bose, 1996) This increase suggests that, despite faring well on its de jure test, the Indian employment security social contract has not fared so well on its de facto test.

To some extent, an increase in the use of ESAMs can be understood as not a de facto failing of the social contract but rather as an attempt to maintain the employment security of core workers during a period of dramatic economic change. However, some of the Indian ESAMs, including breaking up firms so that they will not come under the purview of the IDA (Kuruvilla and Hiers, 1997), effectively strip core workers of their employment security. Moreover, an increase in the use of ESAMs reflects a change in the acceptance of the social contract by the direct parties to the contract. Originally, both direct parties to the social contract, namely public sector employees who benefited from it and the public sector that provided it despite not being legally mandatd to, accepted this contract. However, there is no indication that the private sector would have adopted the practice of providing employment security just when, it seems, it was most difficult to do so. Also, the expansion of the use of ESAMs around the time that large private sector firms were mandated by law to provide employment security indicates that the private sector never accepted the norm of employment security but rather attempted to subvert it from the start. Thus, an increase in the use of ESAMs in the Indian case should not be seen as an 
attempt to maintain employment security for core workers but rather as an attempt to circumvent restrictive labor law.

Although in the independence era it was expected that most workers would soon be absorbed into the modern sector, this did not happen. In both 1971 and 1981 the modern sector employed 9.5\% of the Indian non-agricultural workforce and by 1991 this had decreased to 8.8\%.(Varma et al., 1997) By amending the IDA in the 1970s and 1980s, the percentage of workers within the modern sector who were covered by de jure employment security increased. However, this percentage of workers covered merely became a larger fraction of a small percentage somewhat under $10 \%$. Thus, Indian workers covered by protective labor legislation, including legislation concerning employment security, did not turn out to be the vanguard of a prosperous working class but rather an oasis of relative prosperity within a much larger body of poor, insecure, unprotected workers.

\section{The case of China to the early 1990s}

As in Japan, a minority of laborers in China have benefited from a non-legislated norm of life-time employment (LTE) (Verma and Zhiming, 1995), while employment for the majority of workers in both countries has been less secure. However, while in Japan core employees in large private enterprises have had LTE, in China for most of the period following the 1949 communist revolution there has been essentially no private enterprise. It is core employees generally in large, urban state-owned enterprises (SOEs) that have had LTE in China. The Chinese system of the state providing core SOE employees with LTE is sometimes known as the iron rice bowl $(\mathrm{IRB})^{12}$. The origin of LTE in Chinese industry is not entirely clear. It may be in the mid-1950s, when the Communist Party converted many private industrial and commercial enterprises into SOEs by nationalizing them. Although SOEs were the primary site of the IRB, not all workers in SOEs had this. Most large factories employed a core of regular unionized workers and a periphery of temporary and contract nonunionized workers.(Lockett and Littler, 1983) The core workers had employment security while the peripheral workers did not. During the late 1950s, 27\% of the urban industrial labor force was peripheral.(Lockett and Littler, 1983)

\footnotetext{
${ }^{12}$ The iron rice bowl is sometimes defined more broadly, including a host of benefits that were received by regular state employees in China.
} 
In the mid-1960s the Chinese government implemented an ESAM, the worker-peasant system, that pared down the size of the core workforce in SOEs even further. It did this by instructing all state-owned enterprises to hire less new permanent employees and to transfer less temporary or contract workers to permanent status.(Walder, 1986) Thus the worker-peasant system reduced the number of workers who would attain IRB and the employment security that was a part of it.(Sheehan, 1998) This system was implemented and orchestrated by the state. Doing so undermined the legitimacy of the state in some workers' eyes, as evidenced by the militancy generated in the late 1960s by the consolidation of the worker-peasant system.(Sheehan, 1998) Although unions, comprised of core SOE workers, would presumably be weakened by the worker-peasant system, they did not lead this militancy. This is no surprise given that Chinese unions are mere extensions of the government that serve as a "conveyor belt" between workers and the state, helping to bring about state production and education goals while informaing the state about the needs of workers.(Littler and Lockett, 1983)

In 1978 China abandoned its period of import-substituting industrialization and embarked upon an economic path that further eroded the IRB. Deng Xiaoping decided to begin gradually opening China to the external economy. This exposed China to global economic forces that it was previously largely insulated from and precipitated a move toward aligning Chinese economic policy and industrial organization to the demands of those forces. In the words of the CCP, it precipitated a move from a planned socialist economy to a planned commodity economy.(Han and Morishima, 1992) The IRB was undermined in two primary ways during the early stages of China's broad economic liberalization. First, changes in industrial organization resulted in the growth of new forms of insecure employment. These include the development of Special Economic Zones and Town and Village Enterprises, both sites of insecure employment (Sargeson, 1999), as well as the rapid growth of the private sector, also a site of insecure employment.(Qi, 1996) Second, the thrust of the worker-peasant system was re-enforced by the Contract-Labor System (CLS) to make employment in SOEs even more insecure. While the worker peasant system reduced the number of workers who would attain the employment security of IRB, CLS brought this number down to zero. It did this by forbidding SOEs from hiring new permanent workers or shifting temporary or contract workers to permanent status.(Han and Morishima, 1992) If CLS is fully implemented, it will result in a progressive move, as older permanent employees retire, toward the total absence of workers with the IRB. 
That is, all SOE workers will be contract or temporary workers and so without LTE. However, implementation of the CLS has been slow.(Sheehan, 1998) There has been resistance to implementation of the CLS, and much of this resistance has stemmed from "general ideological principle.”(Sheehan, 1998: 207) Resistance to the CLS has been cited as one reason that many of the previously privileged SOE workers were intense supporters of the 1989 Democracy Movement.(Sheehan, 1998)

\section{Summary}

This section traced the origins and development through the 1980s of employment security norms in our four country cases. In all four countries these norms significantly influenced both expectations and actions. Employment security norms were enabled in these countries in different ways, including through rapid growth in Japan and Korea and through import substitution industrialization strategies in China and India. In all countries the norms benefited directly a minority but crucial and unionized segment of the workforce. Also, in all countries, employment security norms were under pressure for much of the period of their existence. We will now examine the intensification of this pressure in the 1990s and the effects of this intensified pressure on employment security norms in each of our country cases.

\section{Development of Social Contracts From the Early 1990s to the Present}

\section{The case of Japan from the early 1990s to the present}

In the early 1990s, Japan’s bubble economy of the 1980s burst. Stock and real estate values declined rapidly in the early 1990s and remained at low levels throughout the decade. Growth rates averaged 3.5\% from 1985 to 1992 but only .6\% between 1992 and 1995 (Benson, 1998) and have not increased since. Unemployment which ranged 1-2\% during the 1960s and 1970s and 2- 3\% during the 1980s (Benson, 1998) was up to 3.2\% in 1995, 4.4\% in 1999, and a record 4.7\% in early 2000.(Associated Press, 3/15/2000). As with the oil crises of the 1970s and the yen appreciation of the 1980s, poor economic performance in the 1990s precipitated the erosion of LTE. However, the performance of the Japanese economy during the 1990s seemed to suggest an even graver threat to LTE than in previous decades. There emerged in the 1990s 
pessimism about aspects of Japanese industrial organization and practices, including both the keiretsu system of cross-shareholding among member corporations of a business group as well as LTE.(Sako and Sato, 1997) Some developments since the early 1990s reflect this pessimism and bode poorly for LTE while other developments since then suggest an enduring strength of LTE.

Numerous developments since the early 1990s bode poorly for LTE. First, there is a new reluctance among firms within keiretsu networks to bail out troubled affiliates.(Lincoln and Nakata, 1997) Thus, poorly performing Japanese firms, which are currently very numerous, are less likely to be enabled though the support of other firms in their keiretsu network to forego retrenching core employees.(Lincoln and Nakata, 1997) Second, a rationalization of the whitecollar workforce is occurring.(Sako and Sato, 1997) Whether this will result in the demise of LTE among white-collar workers or, as with the earlier blue-collar rationalization, simply an erosion of this norm is not yet clear. Third, employment institutions that promote insecure employment, such as outplacement services, are booming.(Australian Financial Review, 1/18/99). ${ }^{13}$ Fourth, the Japanese Labor Ministry is liberalizing the job placement industry. Whereas agencies in this industry previously were able to offer their services only in the bluecollar market, now they are also able to do so in the white-collar market.(Australian Financial Review, 1/18/99) Fifth, the number of Japanese with temporary jobs has been rising on a monthly basis since September of 1996 while the number of Japanese with permanent employment had declined for 25 straight months as of February 2000.(Dow Jones, 2/28/00) Sixth, the number of Japanese leaving their jobs involuntarily is rising.(Dow Jones, 2/28/000) Seventh, the transfer of workers from large firms to small firms has escalated in recent years, and small firms are less likely than large firms to be sites of LTE.(Lincoln, 1997) Eighth, major employers such as Nissan, Hitachi, and Mitsubishi have recently announced major restructuring plans that will result in the loss of thousands of jobs.(The Straits Times, 1/21/2000)

Other developments since the early 1990s suggest an enduring strength of the LTE norm. First, Rengo, the largest Japanese union confederation, became an important actor in national politics during the 1990s.(Kume, 1998) Rengo strongly resists retrenchment, and its new power in national politics may help Rengo to resist the erosion of LTE.(Rengo, 1998) Second, Nikkeiren, the largest Japanese employer confederation, is making some efforts to maintain

\footnotetext{
${ }^{13}$ On a related note, Rengo, the largest Japanese union confederation, recently set up a temp agency. Rengo's aim in doing this is to find jobs for people laid off due to restructuring and bankruptcies and to protect temps from abuses.(Daily Yomiuri, 10/24/99)
} 
LTE.(Daily Yomiuri, 1/19/2000) ${ }^{14}$ Third, the Ministry of Labor has resisted attempts by firms to reduce their workforces more than it thinks they should.(Lincoln, 1997) Fourth, even when shrinking their workforces, at least some Japanese firms continued to avoid outright retrenchment well into the 1990s. For instance, managers at Japan's top five iron and steel firms reduced employment by one-quarter between 1993 and 1996 without dismissing a single worker.(Gordon, 1998) Fifth, the norm of employment security is still held in high esteem; both workers and managers remain deeply attached to LTE.(Sako and Sato, 1997) Sixth, LTE for core employees has the powerful force of inertia on its side.(Sako and Sato, 1997)

Overall, although it seems likely that the erosion of LTE will continue, it is not yet clear that LTE will disappear as a norm guiding a substantial fraction of Japanese employment relationships. Erosion of LTE began roughly in the 1970s, the same time that the most rapid phase of Japan's postwar growth ended. Erosion of LTE has not abated since then, and it will probably not do so unless a similarly rapid phase of growth begins anew. Even if Japan does not again achieve such rapid growth, LTE is not necessarily doomed. Growth in the 1970s and 1980s was slower than growth in the 1950s and 1960s, and though this slower growth culminated in some ESAMs it did not culminate in LTE's death. Current threats to LTE are emerging in a period of non-growth. Yet if growth were to resume at even a moderate pace these threats may take on less significance.

\section{The case of Korea from the early 1990s to the present}

The tripartite council formed in 1990 gave Korean organized labor a greater voice in policymaking and helped to stabilize industrial relations in Korea. Although confrontational labor relations continued to be pervasive, labor disputes declined and strikes became more moderate.(Kim and Chang, 1998) However, Korean organized labor lost much of its voice in policymaking during the mid 1990s.(Keun Song, 1999) Meanwhile, Korea further integrated with global markets. As a member of the WTO (launched in 1994), Korea's ability to use tariffs and subsidies decreased, thus increasing competitive pressures on Korean firms. Furthermore, in order to join the OECD the Korean government had promised to revise its labor laws to conform

\footnotetext{
${ }^{14}$ Nikkeiren is making this effort and calling for Rengo to agree to wage restraint in return. It is also advocating work-sharing schemes in which workers work less and are paid proportionally less.(Daily Yomiuri, 1/19/2000) Rengo consistently denies that wage restrain is necessary. Nonetheless, Rengo has accepted three straight recordlow pay raises in Japan's annual labor negotiations.(Reuters, 3/15/00)
} 
with more flexible OECD standards by the end of 1996.(KEF, 1997) International pressure was brought to bear on the Korean government to fulfill this promise.(KEF, 1997) ${ }^{15}$

Although labor relations had stabilized since 1990, attempts by the Korean government to increase de jure employment flexibility posed the threat of jeopardizing this stability and provoking a militant labor response similar to the one during the democratization of the late 1980s. This was an especially contentious issue since labor legislation was of increasing importance to upholding the norm of employment security. In order to increase employment flexibility without provoking such a response, the Korean government re-included organized labor in the policy-making process via the Presidential Commission on Industrial Relations Reform, formed in May of 1996.(KEF, 1997) The purpose of the Commission was to prepare a report for the President that could serve as the basis for labor legislation reform.(KEF, 1997) Even the militant and independent KCTU was given representation in the Commission, despite the fact that the Korean government did not yet recognize the KCTU. While the Commission meetings dragged on for 6 months, the KCTU threatened to secede and the FKTU stated that it expected nothing to get accomplished.(KEF, 1997) The FKTU was correct, as the Commission agreed on virtually nothing and submitted an unfinished report to the President in November of 1996.(KEF, 1997) Based upon this, the Korean national legislature passed labor law reforms which influenced de jure employment security much less than originally intended. Whereas the proposed bill originally granted employers broad rights to lay off surplus workers, the new law merely allowed layoffs in emergencies, such as bankruptcy.(KEF, 1997) Furthermore, by the new labor law retrenchment would continue to require government approval.(KEF, 1997)

Shortly following the Commission and the related labor law reform, Korea was hit by the Asian Financial Crisis. The Korean government requested and received aid from the IMF. The IMF then pressured Korea to reduce fiscal expenditures and restructure its banking industry.(Kim and Chang, 1998) Furthermore, as when attempting to join the OECD, the IMF pressured Korea to increase employment flexibility, which was seen as critical in attracting foreign capital. ${ }^{16}(\mathrm{KLI}, 1999)$ Korea then it set up a third tri-partite commission with the purpose,

\footnotetext{
${ }^{15}$ Korea did join the OECD on December 12, 1996.

16 The soundness of the IMF's prescriptions for Korea and the other recipients of IMF aid during the crisis has been seriously undermined. Paul Krugman, Jeffrey Sachs, and most recently Joseph Stiglitz (chief economist at the World Bank during the Crisis) have all called into question these prescriptions, which now seem more a part of the Washington Consensus, US Treasury Department, IMF bureaucratic functionaries, and third-rate IMF economists than they do the more historically informed and empirically considerate kind of neoclassical economics.
} 
as with the second commission, of forming a consensus on how to flexibilize labor which could serve as the basis for changes in labor legislation. Since this third commission operated during the Crisis, it had a greater imperative to act.

The Commission, which was composed of political representatives, managerial representatives, and representatives of both the KCTU and FKTU, agreed upon various reforms. Reforms that benefited organized labor but did not directly pertain to employment security included officially recognizing the KCTU, collective bargaining rights for the public sector, and the freedom of labor unions to be politically active.(Kuruvilla and Erickson, 2000) The focus of the Commission, though, was a dual strategy for bringing greater numerical flexibility to the Korean labor market. This dual strategy was on one hand labor law revisions to permit layoffs in limited circumstances and to permit the use of temporary labor for periods up to one year and on the other hand a social safety net composed of a new unemployment insurance fund and increased unemployment benefits to lessen the blow of layoffs and lessen the insecurity associated with temporary labor.(Kuruvilla and Erickson, 2000) Soon after the Commission came to agreement on all these measures the KCTU threatened to hold a nationwide strike if the agreement was not renegotiated.(WSJ, 2/11/98) The national assembly ignored this threat and quickly wrote the terms of the agreement into law in February of 1998.(Kim and Chang, 1998)

The Crisis took a major toll on employment in Korea, though workers with employment security did not bear the brunt of this. The unemployment rate rose from $2.1 \%$ in October of 1997 to 8.6\% in February of 1998.(Fields, 1999) However, a mere 5.7\% of workers among the unemployed had worked in establishments with more than three hundred employees, establishments where union representation is very high.(Fields, 1999) Temporary and daily workers accounted for the bulk of the unemployed, and $61 \%$ of the unemployed had worked in small establishments employing fewer than ten workers.(Fields, 1999) The fact that workers in small firms and contingent laborers took most of the hit of the Crisis and its aftermath suggests a resilience of the employment security norm in Korea. This norm has only ever been prevalent in the large Chaebol. There are a few reasons to believe it will continue to be prevalent there. First, employment security in the Chaebol has a long tradition, and thus the norm has inertia on its side.(Lee, 2000) Second, job security agreements became the primary collective bargaining issue in 1998.(Kuruvilla and Erickson, 2000) Thus, unions are putting a lot of emphasis on the maintenance of the employment security norm. As a result, several companies have recently 
attempted to guarantee some degree of job security (e.g. Daewoo Precision, Inchon Steel, and Korean Telecommunication).(Kuruvilla and Erickson, 2000) Third, attempts to lay off core workers have been met by a wave of strikes (Kuruvilla and Erickson, 2000), thereby making retrenchment of core workers a less attractive option for employers. Fourth, growth is back in Korea. Korea grew by 10.2\% in 1999 and is expected to grow by 7.7\% in 2000.(FT, 4/28/00) Associated with this, unemployment has come down from its high of 8.6\% in February of 1998 to $4.6 \%$ in October of 1999.(Fields, 1999) ${ }^{17}$

Despite indications that bode well for the endurance of the employment security norm in Korea, there are also indications that bode poorly for this. First, even within the Chaebol, downsizing, lay-offs, and early retirement have emerged as new trends since the crisis began.(Lee, 2000) Second, the size of the workforce with permanent employment continues to shrink. In 1998, the number of permanent wage workers shrank by 10.6\%.(Fields, 1999) Meanwhile, the number of temporary and daily workers continues to rise.(KLI, 1999) Finally, given the post-1987 power of organized labor, it is not clear whether Korea will be able to make adjustment necessary to remain competitive in global markets. This power has enabled organized labor to successfully bargain for higher wages and continued numerical inflexibility, which undermine Korea’s competitiveness in both domestic markets, which have successively been opened up by the WTO, and export markets. In a sense, the Crisis precipitated a gargantuan, economy-wide ESAM. This ESAM has been for Korean business en totem to back down in the face of organized labor militance while retrenching underprivileged labor (And white collar and managerial staff) en masse. Even aside from ethical considerations but rather as a practical matter, it is not clear whether this kind of ESAM will enable privileged Korean laborers to either stave off further erosion of the employment security norm or even to prevent its demise.

\section{The case of India from the early 1990s to the present}

The 1990s brought dramatic change to the Indian economic environment. In 1991, following a balance of payments crisis, the government of India agreed to implement an IMF structural adjustment program (SAP) in exchange for emergency credit. This SAP culminated in

\footnotetext{
${ }^{17}$ This is still nowhere near the pre-crisis level of 2.1\%. Furthermore, the 4.6\% figure does not include those who have left the labor force in frustration at the poor employment prospects following the crisis.(Fields, 1999)
} 
India's New Economic Policy, or NEP. Two important aspects of the NEP are a reduction of fiscal deficits and a reduction in tariff-levels. Both of these aspects accelerated India's move away from its earlier economic environment conducive to employment security. Reducing fiscal deficits undermines employment security by putting pressure on PSUs' budgets and thereby making it more difficult for PSUs to retain redundant workers. Reducing tariff levels undermines employment security by opening up Indian markets to domestic competition. As a result of this competition, Indian public firms and private firms are under more pressure to reduce excess expenditures, including by retrenching redundant workers.

The IMF SAP was not the only instance from the 1990s of foreign involvement in Indian affairs promoting employment flexibility. As a second instance, the World Bank, and many foreign investors, (as well as some, but not all Indian employers) have pressured the Indian government to allow an "exit policy”, or a policy by which employers can retrench industries or close plants.(Kuruvilla and Erickson, 2000) A tripartite committee formed for the purpose of developing an exit policy recommended the creation of a safety net for training retrenched workers and for retrenchment compensation.(Kuruvilla and Erickson, 2000) However, as was the case in Korea, unions have had misgivings about this tripartite committee.(Bhattacherjee, 1999) Furthermore, amendments to legislation that would enable an exit policy have not been passed.(Kuruvilla and Erickson, 2000)

Aside from the NEP and foreign pressures for greater employment flexibility, there were other signs that the norm of employment security was under threat in India during the 1990s. First, with the move of Indian political parties toward more liberalized economic policies, there has been a weakening of ties between union federations and political parties.(De Sousa, 1999) These ties had traditionally been strong and had enabled organized labor to attain many benefits, including employment security. Furthermore, as the government-union coalition has weakened, the government business coalition has strengthened.(Kuruvilla and Erickson, 2000) This bodes especially poorly for organized labor since, as discussed above, there is no indication that the Indian private sector ever supported the employment security norm, and this sector will likely use their closer ties with government to further undermine this norm. Second, the number of sectors of the economy reserved for PSUs has been reduced.(Kuruvilla and Hiers, 1997) Since PSUs have been a bastion of employment security, reducing the number of sectors reserved for PSUs undermines employment security. Third, in order to avoid unions, firms are increasingly 
opening Greenfield non-union plants.(Kuruvilla and Erickson, 2000) Without unions, workers in these plants will be less able to resist erosion of employment security norms. Fourth, employers are increasingly bargaining for greater employment flexibility. A recent study covering 300 collective bargaining agreements in the Indian private sector found that one of two included provisions for greater flexibility.(Venkataratnam, 1997) Fifth, the continuing move toward a larger fraction of contingent workers in the workforce accelerated in the 1990s.(Dev, 2000) Sixth, the National Labor Commission was set up in the 1990s with the aim of rationalizing and flexibilizing national labor law.(Bhattacherjee, 1999)

Despite many signs that the employment security norm is under threat in India, some signs suggest at the resilience of this norm. For instance, the National Labor Commission has not yet succeeded in rationalizing or flexibilizing national labor law.(Bhattacherjee, 2000) This underscores that, despite the weakening of relations between the Indian government and organized labor, these relations are still strong enough to slow reform. Second, redundancy is greatest in the public sector. In fact, only $12.9 \%$ of redundant employees work in the private sector.(SAAT, 1996) This bodes well for the employment security norm since public sector unions are more effective than private sector unions at avoiding restructuring.(Kuruvilla and Hiers, 1997) Third, unions have been relatively successful at resisting privitization.(Candland, 1996) Although the first partial privitization of a PSU occurred in 1991 (Candland, 1996), little occurred in following years.(Dev, 2000)

It seems there are more signs that the employment security norm is under threat in India than there are signs of this norm's resilience. Nonetheless, many Indian workers are still covered by de jure employment security and so employment security is still a significant factor in India industrial relations. In 1996, there were 22 million workers covered by employment security, 4.4 million of whom were redundant.(SAAT, 1996) Furthermore, restructuring through the NRF program was not met by masses of workers giving up their secure employment.(SAAT, 1996) Part of the reason for this is the VRS does not provide adequate incentive to voluntarily retire. Monetary incentives are low. ${ }^{18}$ (SAAT, 1996) Another reason is the slow growth of employment in India's formal sector.(SAAT, 1996) Thus, workers who take voluntary retirement then have little opportunity to get a job outside of the informal sector, where work conditions and compensation are much worse than in the formal sector. Some have called for increasing the

\footnotetext{
${ }^{18}$ Golden handshakes are pewter at best.
} 
incentives for redundant workers to sign up for the VRS.(SAAT, 1996) There has also recently been more talk of developing a social safety net for workers retrenched due to privitization.(Economic Times, 3/24/00) This parallels the Korean post-Crisis experience, when a social safety net was developed at the same time that employment flexibility was increased. Also similar to the Korean experience, this net would be devised for organized sector workers who are retrenched, not for workers who had no employment security to start with. Aside from India's prospective social safety net, the NRF, too, cushions the blow of retrenchment only for organized sector workers. ${ }^{19}$ (SAAT, 1996)

By the end of the 90s the prospects for employment security in India had dimmed. After the central government was toppled a few times within a few years, the Bharatiya Janata Party (BJP) has finally established a relatively stable coalition at the center. This is significant for employment security norms because the BJP is squarely backing rapid liberalization. Furthermore, the Congress Party, which is the major opposition party, has expressed that it will not resist BJP efforts to liberalize. In this environment conducive to liberalization, the central government recently accelerated the stalled privitization drive. ${ }^{20}$ Also, a union-opposed major modification of a major piece of labor legislation has nearly made its way through parliament. ${ }^{21}$ Thus recent indications from the center suggest the employment security norm in India will continue to be weakened. From the mid-1980s into the 1990s, the social contract concerning employment security in India fared pretty well on its de jure test despite not faring well on its de facto test. Recent indications suggest that this social contract will probably falter on its de jure test as well.

\section{The case of China from the early 1990s to the present}

By the early 1990s, China was in a legitimacy bind concerning employment security. As with the consolidation of the worker-peasant system in the mid-1960s, the implementation of the CLS in the late 1980s resulted in strong resistance from workers who felt their employment security, or prospect for employment security, was being undercut. This resistance was a

\footnotetext{
${ }^{19}$ The NRF also provides resources for employment generation schemes in the unorganized sector.(SAAT, 1996) However, it provides no benefits specifically geared toward unorganized sector workers who are retrenched.

${ }^{20}$ Modern Foods was sold to Hindustan Lever and Indian Airlines was put on the blocks.
} 
testament to the strength of the employment security norm for SOE workers in China. In the terms of this paper, it was an instance of employers undermining their legitimacy (in the eyes of their employees) by attempting to revoke the social contract concerning employment security. However, by the 1990s China had gradually moved along the path toward a more liberal and open economy for over a decade and this had increased China's rate of GNP growth substantially.(Rawski, 1999) However, it had also progressively undermined the IRB, and continued high rates of growth seemed to demand more of this.(Hannan, 1998) Throughout the 1990s, the CCP attempted to balance the legitimacy constraints of the need to ensure continuing rapid growth and the need to satisfy SOE workers.

During the 1990s there was no indication that new employment in the emerging market environment would help to rekindle the norm of employment security. Formal employment growth outpaced labor force growth until 1995, from which point formal employment remained essentially stable in absolute terms while declining rapidly relative to informal employment as a share of the workforce.(Rawski, 1999) However, even formal employment was no longer secure. Temp workers were the fastest expanding sector of employees in SOEs.(Sargeson, 1999) By 1994, 26\% of the SOE workforce was on contract.(Sargeson, 1999) ${ }^{22}$ The fastest growing sources of formal employment during the 1990s were private enterprises and town and village enterprises (TVEs), neither of which are bastions of employment security. Overall, the percentage of urban workers on contract increased from 12\% in 1990 to 41\% in 1996.(Sargeson, 1999) However, as with in SOEs, many workers in the rapidly growing private enterprises and TVEs in the 1990s were not even on contract but were instead temps.(Sargeson, 1996)

As new insecure employment emerged in China during the 1990s, the Chinese Communist Party (CCP) sent signals that old secure employment would not last. At the Third Plenum meeting of the CCP in 1993, the CCP announced that China was officially switching to a market economy.(Prokopenko, 1999) Then in 1996, the CCP decreed that creating employment was not the Party's major task.(Hannan, 1998) Meanwhile, urban unemployment rose from $3.7 \%$ in 1993 to $7 \%$ in $1997 .{ }^{23}$ (Rawski, 1999) Part of this rise stemmed from the relaxing of

\footnotetext{
${ }^{21}$ Modification of the Trade Unions Act has been passed by parliament and is awaiting notification.(Bhattacherjee, 2000)

${ }^{22}$ Employment in SOEs increased from 103.5 million in 1990 to 110.4 million in 1997 though it declined as a share of the total urban workforce.(Sargeson, 1999)

${ }^{23}$ These figures are derived by Rawski from official CCP figures of urban unemployment, which are notoriously unreliable, by assuming that $40 \%$ of furloughed workers have obtained new jobs.
} 
restrictions on rural urban migration and the consequential flood of urban areas by peasants.(Lu et al., 1997) However, part of this also resulted from retrenchment in SOEs. China has not pursued wholesale privitization of SOEs in their "gradualist" transition to a market economy.(O’Leary, 1998) Instead, the CCP has endeavored to make SOEs more efficient through restructuring and bolstering of competitive forces.(O’Leary, 1998) Yet in the mid 1990s, this restructuring and stoking of competitiveness began to culminate in retrenchment en masse. In 1996 the number of SOE workers retrenched reached 10 million. ${ }^{24}$ (Prokopenko, 1999) In 1998 this figure was down to 6.1 million.(Associated Press, 3/29/99) However, in 1999 it rose to 11.7 million SOE workers.(Reuters, 3/7/00) The rate of redundancy in SOEs has been estimated at 30\%, though generally without reference to a specific year.(Rawski, 1999; Hannan, 1998) Whether or not high levels of redundancy remain or retrenchment continues, mass SOE retrenchment in recent years suggests that the number of employees protected by the IRB is rapidly dwindling.

Although the significance of SOEs to the Chinese economy has declined ${ }^{25}$, the CCP continues to make some effort to maintain its legitimacy in the eyes of SOE workers. First, there has been some shifting of redundant SOE workers to subsidiaries in order to stave off outright dismissal.(Rawski, 1999) This is analogous to the very prevalent Japanese ESAM of shifting redundant private workers to related subsidiaries. Second, the CCP replaced the six-day work week in SOEs with a five-day work week in order to reduce the need for retrenchment.(Hannan, 1998) Third, China's unemployment insurance system is being expanded to include more workers, workers who predominantly are employed in SOEs.(China Daily, 3/15/99) Fourth, instead of always practicing outright dismissal, China has furloughed many redundant SOE workers since the early 1990s. Furloughed workers do not report to work yet are paid a reduced salary while they seek new employment. ${ }^{26}$ (Rawski, 1999) Fifth, employment regulations were extended to include contract and temporary workers in 1995, the kinds of workers that retrenched SOE workers probably often end up as.(Sargeson, 1999) However, these regulations are ignored with impunity.(Sargeson, 1999) Sixth, the CCP is encouraging provincial

\footnotetext{
${ }^{24}$ Compare this to the estimate cited above of 4.4 million total redundant workers in Indian PSUs in 1996. China retrenched more than twice this amount in 1996 alone. For better or worse, Indian democracy seems to slow brutal dislocations toward efficiency.

${ }^{25}$ SOEs accounted for three-quarters of industrial output in 1981 and only one-third in 1997.(Prokopenko, 1999)
} 
governments to grow their job retraining programs for SOE workers who are retrenched.(Hannan, 1998) Nonetheless, about one-half of those retrained do not find jobs.(Far Eastern Economic Review, 2/25/99) Seventh, China's policy is to pay pensions to retrenched SOE workers, and the CCP has recently claimed it will raise these pensions.(Associated Press, 8/28/99) However, not long before it made this claim, the CCP was merely claiming it would pay at least $50 \%$ of those pensions it owed which it had heretofore failed to pay.(Associated Press, 4/13/99)

Despite these many efforts by the CCP to retain its legitimacy in the eyes of SOE employees, the failure of the CCP to ensure continuing employment for retrenched SOE workers or even to meet its pension obligations indicates the declining significance of SOE workers in the eyes of the CCP. While SOE employment continues to shrink as a fraction of the total workforce, this significance will only decline further. Furthermore, the fraction of SOE workers with the IRB will also likely continue to decline. Predicting the future of the employment security social contract in China is easier than it is for the cases of Japan, Korea, or even India. Unless current or recent SOE workers mount a significant challenge to CCP rule, the CCP will continue to restructure SOEs in the hopes of maintaining China's period of sustained rapid growth. As the CCP continues to restructure SOEs, the last vestiges of the IRB and the employment security norms that are a part of it will likely be destroyed.

\section{Discussion}

We have discussed both the emergence of and undermining of the employment security norm among core workers in the modern industrial sectors of China, India, Japan, and South Korea. We will now address the question of whether these norms will be completely eroded and the impact such erosion would have on core and periphery workforces in our country cases.

A key question is whether there has been or will be a change from a system of employment marked by a core with the norm of employment security and a periphery without the norm of employment security to a system of employment marked by a norm of employment insecurity for essentially all workers. Although the previous system has been undermined in all

\footnotetext{
${ }^{26}$ In a sense, the furloughs can be seen as an ESAM. They protect redundant workers while these workers seek new unemployment. However, it is not clear what happens if such redundant workers do not find new employment or
} 
four countries, it has not been entirely eradicated and thus there has not been a full shift to the latter system in any of the four countries. Within the section concerning the 1990s above, we mentioned forces mitigating for and against continuation of employment security norms for each of the four countries. Comparing the four countries in terms of both these forces and more general considerations, we suspect that there is some likelihood of these norms enduring to a significant extent in Japan and Korea but little likelihood of this in India and even less in China. In all four countries there has been a rapid rise in the size of the contingent workforce in recent years. This indicates that the core workforce where employment security norms have prevailed in the past has likely shrunk in all countries, and if this trend continues employment insecurity will eventually prevail in all four countries. On the other hand, employment security norms have the force of inertia on their side in all four countries. This force probably has some significance in Japan and Korea. Employment security for the core workforces in Japan and Korea has been, in combination with functional flexibility, part of an integrated industrial relations strategy geared toward quality and productivity. This strategy has contributed to Japan and Korea's longstanding success in export markets. Furthermore, this strategy has been regarded by many as superior to other industrial relations strategies around the globe.(Smitka, 1991; Nishiguchi, 1994) Then again, Korea and Japan’s integrated industrial relations strategy that has included employment security for core workforces was highly successful when the Korean and Japanese markets were largely closed to foreign competition and when Korean and Japanese wage costs were much lower. Whether it could remain competitive as the WTO continues to pry open these markets and as Japanese and Korean capital continues to move abroad in search of cheaper labor is anybody's guess.

The force of inertia concerning employment security probably has less significance in China and India. China and India pursued an ISI (import substitution industrialization) strategy during much of the period when employment security norms prevailed in these countries. However, they are radically altering their economic strategies toward higher exports, and this will require much higher levels or quality and productivity. Unlike in the cases of Japan and Korea, there is no Chinese or Indian precedent that suggests China or India could achieve high levels of quality and productivity under a system of employment that includes employment security for core workers.

how long they continue to receive an income as furloughed workers. 
Recent economic events have posed variable threats to employment security norms in our four country cases. These norms have come under major stress in Japan and Korea as a result of economic crises. The Korean Chaebols responded to the Crisis by downsizing their workforces some and laying off some core workers. Korea nonetheless emerged from the Crisis with employment security norms somewhat intact. In some ways the Crisis actually underscored the strength of employment security norms protecting the core Korean workforce. The peripheral workers suffered the brunt of the Crisis, including through mass retrenchment, while core union workers were largely spared (although not white collar and managerial employees). Furthermore, strong, independent, militant Korean unions struggled during and after the Crisis to preserve employment security norms, and they have succeeded in getting some Korean businesses to codify what have long been tacit employment security norms by writing them into collective bargaining agreements. Japan is still suffering through its economic crisis and this crisis continues to be a major threat to employment security norms. As opposed to the Korean case, Japanese unions, though strong at the workplace, have not successfully defended employment security norms during Japan’s economic crisis. However, Japan’s largest union federation, Rengo, has recently gained strength and prominence in national politics, and is bringing about some consolidation in union structures to strengthen its base. Furthermore, Rengo as well as Japan's largest employers' federation, Nikkeiren, the Japanese Ministry of Labor, and Japanese firms and workers are all making attempts to defend employment security norms. Regardless of these attempts, changes in Japanese industrial organization may make LTE unsustainable. As Japan increasingly relies on ESAMs, such as by shifting a growing number of core workers to small firms, keiretsu ties that enable many ESAM's are weakening. That is, a historically critical support for employment security norms is weakening at the time when it is needed most to defend these norms.

To an even greater extent than in Korea and Japan, recent economic events have threatened employment security norms in India and China. India and China have radically reoriented their development strategies toward greater openness, competitiveness, and growth, and this reorientation continues in both countries. Retrenching redundant workers is widely regarded as an essential component of India's NEP, and both the government and the primary opposition party support the NEP. This is indicative of the weakening relationship between the government/political parties and unions, who generally oppose the NEP. At the same time, the 
relationship between the government/political parties and business, which strongly supports the NEP and numerical flexibility in particular, is becoming closer. Thus, whereas in Japan's ongoing crisis the critical ILR actors have shown some support for employment security norms, generally only unions have shown this support in India. Although the Indian government has not yet legislated an undermining of extant employment security norms- and it is hesitant to do so given that strong union resistance may create a backlash that threatens its rule- many employers are either bargaining for retrenchment or craftily violating the spirit if not the letter of laws that restrict it. As with India's NEP, retrenching redundant workers is widely regarded as an essential component of China’s drive to achieve success in a globally integrated market economy. However, unlike in the case of India, the Chinese government apparently does not have to contend with unions that could threatens its rule since Chinese unions are little more than an appendage of the Chinese government. Still, in the past this government has faced the threat of revolt if it did not appease the critical core industrial workforce. However, the Chinese government's retrenchment in recent years of tens of millions of SOE workers indicates this is no longer a major threat, and it becomes an even smaller threat as the SOE workforce continues to shrink rapidly. Thus while the Indian government and business have a good hand in their effort to undermine employment security in India, the Chinese government, in its effort to undermine employment security in China, holds all the cards. In sum, China will likely soon achieve a system of employment marked by employment insecurity for essentially all workers. India is less likely to achieve this than China, but India is probably more likely to achieve it or to achieve it rapidly than is Japan or Korea.

While the likelihood of a system of employment marked by employment insecurity for essentially all workers clearly varies for the countries we are examining, the effects of such a system for the core and peripheral workforces within these countries are not entirely clear. Neoclassical economists generally argue that employment security contributes to inflexibility that slows the growth of a nation's economy and creates unemployment. This reconciles well with the experiences of India and China during much of the postwar period, when low growth was matched by high unemployment. However, some academics that focus on workplace institutions argue that employment security can, when part of specific broader institutional frameworks, increase productivity and contribute to growth. This reconciles well with the experiences of Korea and Japan during much of the postwar period, when high growth was 
matched by low unemployment. For the sake of argument, assuming that employment security norms for core workers, (who have always been a minority in our country cases), are having negative effects on growth and employment today, peripheral workers, (who have always been a majority), would seem to have at least two reasons to hope for the continued erosion of these norms. First, governments would likely attempt to legitimate this erosion by devising components of a social safety net that benefits peripheral workers. This has already happened in Korea, where the government recently devised an unemployment insurance scheme that covers some of these workers. Second, continued erosion would lead to higher growth for the economy (the neo-classical argument) and possibly higher income for themselves while reducing the chance that they would face unemployment. Core workers would have less reason than peripheral workers to hope for the continued erosion of employment security norms, at least over the short term. However, even assuming this erosion would lead to higher growth and employment, it is not clear whether or not either core workers or peripheral workers would benefit from it. To determine this, one would have to address the question of what broader social ramifications a complete erosion of employment security norms would have, a difficult question that we will not address here. One would also have to address the fact that unions are

currently comprised of core workforces in China, India, Japan, and Korea. Undermining core workforces by making their employment insecure could weaken unions and thereby weaken labor representation in business and political forums. To the extent that strong labor representation in these forums benefits all workers, the complete erosion of core workforce employment security would harm both core and peripheral workforces. For instance, labor legislation benefiting the entire workforce would less likely be passed. Moreover, increased growth enabled by tearing up the core workforce's employment-security social contract might leave unions too weak to ensure that any workers share in the benefits of this increased growth.

\section{Conclusion}

In this comparative essay, we examined the process of institutionalization of the norm of employment security in four large Asian nations. The institutional features that supported the growth of this norm varied from country to country. In both India and China, large public sectors 
under import substitution industrialization strategies were important institutional features that supported employment security. Further in India, supportive legislation given strong unionpolitical party relationships extended this norm to the private sector as well. In contrast, in Korea and Japan, the norm was developed by employers as a function of the need to develop strong internal labor markets. The norm in these countries was also buttressed by strong economic growth during the 1960-1990 period.

The norm of employment security has eroded in all four countries in the 1980s and 1990s in particular. While economic crises contributed to this erosion, particularly in Japan and Korea, liberalization of the economies of China and India , and the consequent increase in competition and firm restructuring were an indirect cause as well. Our assessments about the future of employment security norms presents a mixed picture. We are more hopeful about the norm continuing in Japan given its entrenched internal labor market features and the ostensibly strong support that all actors, (labor, management, government and society at large) have for preserving the norm, provided that the economy emerges out of its recession. We are hopeful about employment security in Korea given recent legislative changes that has provided unions with a greater voice in decisionmaking, and the strong mobilization efforts of Korean unions who have had some bargaining successes of late. We are somewhat less hopeful about employment security continuing in India, particularly given the government's commitment to continued liberalization and privatization of the state sector, weakening union power nationally, and continued efforts to change labor law. We have little hope about the continuance of employment security in China, given the legal introduction of short term contracts and the privatization of the state owned sector, although the ability of Chinese unions to reverse the erosion in employment security is unknown.

Although the norm of employment security has only directly benefited a minority of workers in each of our country cases, the erosion of this norm is concomitant with an increase in inequality in all these cases. This may seem counterintuitive given that eroding employment security norms lowers the gap between core and periphery workers. However, it also increases the gap between workers and non-workers while having broader social ramifications that we were not able to explore much in this paper. This issue deserves further attention, especially since increasing inequality will likely be a source of major debate in the years ahead. 


\section{Bibliography}

Amsden, Alice. 1989. Asia's Next Giant; South Korea and Late Industrialization. New York: Oxford University Press.

Associated Press. 3/15/00. "Cheers! Laid-off Men Try to Shake the Restructuring Blues".

Associated Press. 3/29/00. "Tougher Competition for New Jobs in China as Layoffs Continue".

Associated Press. 4/13/99. "China Expects 7 Million Will Lose Jobs in State Factories This Year”.

Associated Press. 8/28/99. "China to Boost Pay-outs to Unemployed".

Audi, Robert, ed. 1999. The Cambridge Dictionary of Philosophy; Second Edition. Cambridge: Cambridge University Press.

Australian Financial Review. 1/18/99. "Spring Wage Ritual Highlights Need for Reform”.

Basu, Kaushik. 1996. "Legal and Institutional Prerequisites of Market Reform in India”, IRIS-India Working Paper No. 11. College Park: IRIS Center.

Benson, John. 1998. “Labor Management During Recessions: Japanese Manufacturing Enterprise in the 1990s”. Industrial Relations Journal. Volume 29 Number 3.

Bhattacherjee, Debashish. 1999. “Organized Labor and Economic Liberalizaton; India: Past, Present and Future”, discussion paper. Geneva: International Labor Organization.

Bhattacherjee, Debashish. 2000. Personal correspondence via e-mail.

Blackburn, Simon. 1994. The Oxford Dictionary of Philosophy. Oxford: Oxford University Press.

Bose, Annavajhula. 1996. "Subcontracting, Industrialisation and Labouring Conditions in India: an Appraisal”. Indian Journal of Labor Economics. Volume 39 Number 1.

Candland, Christopher. 1996. "Labor Institutions and Industrial Restructuring in India”, IRIS-India Working Paper No. 24. College Park: IRIS Center.

Chan, JCM, Li, NY and D Sculli. 1989. "Labor Relations and the Foreign Investor in the Shenzhen Special Economic Zone of China”. Journal of General Management. Volume 14 Number 4.

Chang, Ha-joon, Park, Hong-jae and Chul Gyue Yoo. 1998. "Interpreting the Korean Crisis: Financial Liberalisation, Industrial Policy and Corporate Governance”. Cambridge Journal of Economics. Volume 22, p. 735-746.

China Daily. 3/15/99. "China: Unemployment Benefits to Expand".

Clifford, Mark. 1997. Troubled Tiger; The Unauthorised Biography of Korea, Inc. New York: ME Sharpe.

Cook, Sarah and Margaret Maurer-Fazio. 1999. The Workers' State Meets the Market; Labor in China's Transition. London: Frank Cass.

Cusumano, Michael. 1989. The Japanese Automobile Industry; Technology and Management at Nissan and Toyota. Cambridge: Harvard University Press.

D’Souza, Errol. 1994. “Job Insecurity and Labor Market Flexibility”. Indian Journal of Labor Economics. Volume 37 Number 4.

Dahrendorf, Ralf. 1959. Class and Class Conflict in Industrial Society. Stanford: Stanford University Press.

Dahrendorf, Ralf. 1975. Conflict and Contract; Industrial Relations and the Political Community in Times of Crisis. Liverpool: Liverpool University Press.

Daily Yomiuri. 1/19/00. "Spring Labor Offensive Must Move With the Times".

Datt, Gaurav. December 11, 1999. "Has Poverty Declined Since Economic Reforms? Statistical Data Analysis”. Economic and Political Weekly.

Debgupta, Shub. 1997. The Effects of Indian Anti-Retrenchment Laws on a Multi-Sector Economy, MS Thesis for Cornell University.

DeSousa, Valerian. 1999. “Colonialism and Industrial Relations in India”, in Colonialism, Nationalism, and the Institutionalization of Industrial Relation in the Third World. Kuruvilla, Sarosh and Bryan Mundell, eds. Stamford: Jai Press.

Dev, S Mahendra. January 15, 2000. “Economic Liberalisation and Employment in South Asia- 2”. Economic and Political Weekly.

Dev, S Mahendra. January 8, 2000. "Economic Liberalisation and Employment in South Asia- 1”. Economic and Political Weekly. 
Donaldson, Thomas and Thomas Dunfee. 1999. Ties That Bind; A Social Contracts Approach to Business Ethics. Boston: Harvard Business School Press.

Dow Jones. 2/28/00. “Japan’s January Jobless Rate 4.7\%; Flat Vs Revised December Rate”.

Economic Times. 3/24/00. "Government Plans Social Security for PSU Staff After Sell-off”.

Elliott, John. 1978. Conflict or Co-operation? The Growth of Industrial Democracy. London: Kogan Page Limited.

Far Eastern Economic Review. 2/25/99. “Labor; Back to School; Job Retraining Isn’t Much Help to Older Unemployed."

Fields, Gary. 1993. A Proposed Employment Insurance System For Korea. Seoul: Korea Labor Institute.

Fields, Gary. November 1999. "The Employment Problem in Korea”.

Financial Times (FT). 4/28/00. “Asian Tiger Springs Back to Health”.

Freund, Elizabeth. 1998. “Downsizing China’s State Industrial Enterprises: The Case of Baoshan Steel Works”, in Adjusting to Capitalism; Chinese Workers and the State. O’Leary, Greg, ed. New York: ME Sharpe.

Gaus, Gerald. 1999. Social Philosophy. New York: ME Sharpe.

Gordon, Andrew. 1985. The Evolution of Labor Relations in Japan Heavy Industry, 1853-1955. Cambridge: Harvard University Press.

Gordon, Andrew. 1998. The Wages of Affluence; Labor and Management in Postwar Japan. Cambridge: Harvard University Press.

Hajela, PD. 1998. Labor Restructuring in India; A Critique of the New Economic Policies. New Delhi: Commonwealth.

Han, Jlanwel and Motohiro Morishima. 1992. “Labor System Reform in China and Its Unexpected Consequences”. Economic and Industrial Democracy. Volume 13, p. 233-261.

Hannan, Kate. 1998. Industrial Change in China; Economic Restructuring and Conflicting Interests. London: Routledge.

Helleiner, Eric. 1997. “Braudelian Reflections on Economic Globalisation”, in Innovation and Transformation in International Studies. Gill, Stephen and James Mittelman, eds. New York: Cambridge University Press.

Ho Keun, Song. 1999. “Challenge and Choice of Korea’s Labor Unions in Democratization and Globalization”. Seoul: Department of Sociology, Seoul National University.

Holmstrom, Mark. 1984. Industry and Inequality; The Social Anthropology of Indian Labor. Cambridge: Cambridge University Press.

Howard, Pat. 1988. Breaking the Iron Rice Bowl; Prospects for Socialism in China's Countryside. New York: ME Sharpe.

Howell, Jude. 1993. China Opens its Doors; The Politics of Economic Transition. Boulder: Lynne Rienner.

Jacoby, Sanford. 1989. "Pacific Ties: Employment Systems in Japan and the US Since 1900”, working paper series 167. Los Angeles: UCLA Institute of Industrial Relations.

Kawahito, Kiyoshi. 1990. "Labor Relations in the Japanese Automobile and Steel Industries”. Journal of Labor Research. Volume 6 Number 1.

Khan, Azizur Rahman. April 1996. “Globalization, Employment and Equity: The China Experience”. Geneva: International Labor Organization.

Khan, Azizur Rahman. August 1996. "The Impact of Recent Macroeconomic and Sectoral Changes on the Poor and Women in China”. Geneva: International Labor Organization.

Kim and Chang Law Offices. 1998. Korean Labor and Employment Laws; An Ongoing Evolution. Seoul: Korea Labor Institute.

Kim, Jung-won. 1989. Dual Commitment to Company and Union in Korea- A Study of Two Textile Firms and Their Labor Unions, dissertation for University of Wisconsin-stout.

Kochan, Thomas, Katz, Harry, and Robert McKersie. 1986. The Transformation of American Industrial Relations. New York: Basic Books.

Korea Employers Federation (KEF). 1997. Korea’s Industrial Relations Reform. Korea: KEF.

Korea Labor Institute (KLI). October 1999. "The Economic Crisis and Labor Market Policies in Korea: Labor Market Outcomes and Policy Issues”, prepared for the World Bank.

Korzec, Michael. 1992. Labor and the Failure of Reform in China. New York: St Martin's Press.

Krishnan, VN. 1981. "India”, in International Handbook of Industrial Relations. Blum, Albert, ed. Westport, CT: Greenwood.

Kume, Ikuo. 1998. Disparaged Success; Labor Politics in Postwar Japan. Ithaca: Cornell University Press.

Kuruvilla, Sarosh and Christopher Erickson. April 2000. "Change and Transformation in Asian Industrial Relations". 
Kuruvilla, Sarosh and Wesley Hiers. December 1997. “Globalization and Employment Relations in India”. ILO Eastmat.

Kuruvilla, Sarosh, Katz, Harry and Lowell Turner. 1994. "Industrial Relations System Reform in Korea: Principles and Policies in IR Systems Design”. Seoul: Korea Labor Institute.

Lacey, AR. 1996. A Dictionary of Philosophy; Third Edition. London: Routledge.

Lee, Byoung-hoon. 2000. Personal correspondence via e-mail.

Lee, Chung-hoon and Fun-koo Park. 1991. Emerging Labor Issues in Developing Asia. Seoul: Korea Development Institute.

Lincoln, James and Yoshifumi Nakata. 1997. "The Transformation of the Japanese Employment System; Nature, Depth, and Origins”. Work and Occupations. Volume 24 Number 1.

Lindstrom, Lars. 1993. Accumulation, Regulation, and Political Struggles; Manufacturing Workers in South Korea. Stockholm: University of Stockholm Department of Political Science.

Littler, Craig and Martin Lockett. Winter, 1983. “The Significance of Trade Unions in China”. Industrial Relations Journal. Volume 14 Number 4.

Lu, Xiaobo and Elizabeth Perry, eds. 1997. Danwei: The Changing Chinese Workplace in Historical and Comparative Perspective. New York: ME Sharpe.

Markandan, KC. 1966. Directive Principles in the Indian Constitution. Bombay: Allied Publishers Private.

Mitchell, Tony. 1988. From a Developing to a Newly Industrialised Country: The Republic of Korea, 1961-82. Geneva: International Labor Office.

Mo, Jongryn and Chung-in Moon, eds. 1999. Democracy and the Korean Economy. Stanford: Hoover Press.

Monga, ML. 1983. Industrial Relations and Labor Laws in India; Their Implementation and Awareness. New Delhi: Deep and Deep Publications.

Nakamura, Keisuke and Michio Nitta. March 1993. "Development in Industrial Relations and Human Resource Practices in Japan."

Nikkeiren. 1996. “Creating a Dynamic Economy Through Structural Reform”, position paper. Tokyo: Japan Federation of Employers’ Associations.

Nikkeiren. 1997. "Structural Reform- The Search for a Third Option; Employment Stability and Improved National Qualityof Life”, position paper. Tokyo: Japan Federation of Employers’ Associations (Nikkeiren).

Nikkeiren. 1998. "Searching for a Third Way Out of the Crisis", position paper. Tokyo: Japan Federation of Employers' Associaton.

Nishiguchi, Toshihiro. 1994. Strategic Industrial Sourcing; The Japanese Advantage. New York and Oxford: Oxford University Press.

O’Leary, Greg. 1998. “The Making of the Chinese Working Class”, in Adjusting to Capitalism; Chinese Workers and the State. O'Leary, Greg, ed. New York: ME Sharpe.

O’Neill, Kathleen. 1988. “Industrial Relations in Korea: Will Korea Become Another Japan?” Comparative Labor Law Journal. Volume12, p. 360-392.

Park, Se-il. 1988. “Labor Issues in Korea’s Future”. World Development. Volume 16, Number 1.

Park, Se-il. Spring 1993. "The Role of the State in Industrial Relations: The Case of Korea”. Comparative Labor Law Journal. Volume 14, Number 3.

Park, Young-bum and Michael Lee. 1993. "Economic Development, Globalization, and Practices in Industrial Relations and Human Resource Management in Korea”, from conference in Seoul, August 1993.

Park, Young-bum. 1990. Public Sector Labor Market and Privatization in Korea. Seoul: Korea Labor Institute.

Park, Young-bum. 1993. Labor in Korea. Seoul: Korea Labor Institute.

Park, Young-bum. 1996. Labor Trends in the 1990s in Korea. Seoul: Korea Labor Institute.

Price, John. 1997. Japan Works; Power and Paradox in Postwar Industrial Relations. Ithaca: Cornell University Press.

Proceedings of Workshop. 1992. Social Dimensions of Structural Adjustment in India. Geneva:International Labor Organisation.

Prokopenko, Joseph. 1998. "Privatization: Lessons from Russia and China”, enterprise and management development working paper EMD/24/E. Geneva: International Labor Organization.

Qi, Wang. 1996. Job Change in Urban Cities; An Assessment of Socialist Employment Relationship. Frankfurt: Peter Lang.

Ramaswamy, EA. 1984. Power and Justice; The State in Industrial Relations. Delhi: Oxford University Press.

Ramaswamy, EA. 1997. A Question of Balance; Labor, Management and Society. Delhi: Oxford University Press.

Rawski, Thomas. 1999. “China: Prospects for Full Employment”, employment and training papers 47. Geneva: International Labor Organization. 
Rengo. 1998. We This if Rengo; Japanese Trade Union Confederation. Japan: Rengo.

Reuters. 3/7/00. "China Sees 11.5 Million Urban Jobless at End of 2000".

Rhodes, Martin and Yves Meny. 1998. The Future of European Welfare; A New Social Contract? Great Britian: Macmillan Press.

Sako, Mari and Hiroki Sato. 1997. Japanese Labor and Management in Transition; Diversity, Flexibility and Participation. London: Routledge.

Sargeson, Sally. 1999. Reworking China’s Proletariat. New York: St Martin’s Press.

Sastry, CM. 1991. “Contract Labor in the Organised Industrial Sector”. Indian Journal of Labor Economics. Volume 34 Number 2.

Sened, Itai. 1997. The Political Institution of Private Property. Cambridge: Cambridge University Press.

Sheehan, Jackie. 1998. Chinese Workers; A New History. London: Routledge.

Silverman, Bertram, Vogt, Robert and Murray Yanowitch, eds. 1993. Double Shift; Transforming Work in Postsocialist and Postindustrial Societies. New York: ME Sharpe.

Singh, CSK. 1998. Indian Labor Conference; Conclusions. New Delhi: Manak Publications.

Singh, Daljit and Reza Siregar, eds. 1997. Asean and Korea; Trends in Economic and Labor Relations. Singapore: Seng Lee Press.

Skolka, Jiri and Michel Garzuel. 1978. "Income Distribution by Size, Employment and the Structure of the Economy: A Case Study for the Republic of Korea”, World Employment Programme Research Working Papers. Geneva: International Labor Office.

Smitka, Michael. May, 1989. "Competitive Ties; Subcontracting in the Japanese Automotive Industry”, abstract.

Smitka, Michael. 1991. Competitive Ties; Subcontracting in the Japanese Automotive Industry. New York: Columbia University Press.

Song, Ho Keun. 1999. "Labor Unions in the Republic of Korea: Challenge and Choice”. Geneva: International Labor Organization.

South Asia Multidisciplinary Advisory Team (SAAT). “Economic Reforms and Labor Policies in India”. Geneva: International Labor Organization.

Taira, Koji. 1970. Economic Development and the Labor Market in Japan. New York: Columbia University Press.

Takahashi, Yukichi. 1997. “The Labor Market and Lifetime Employment in Japan”. Economic and Industrial Democracy. Volume 18 p. 55-66.

The Straits Times (Singapore). 1/21/00. "Sharing Jobs to Save Jobs".

Tobias, George and Robert Queener. 1968. India’s Manpower Strategy Revisited 1947-1967. Bombay: NM Tripathi Private.

Varma, AP, Chauhan, PS and MM Rehman, compilers. 1997. Indian Labor: A Select Statistical Profile. New Delhi: Manak Publications.

Verma, Anil, Kochan, Thomas and Russell Lansbury. 1995. Employment Relations in the Growing Asian Economies. London: Routledge.

Vogel, Ezra, Lindauer, David. 1997. “Toward a Social Compact for South Korean Labor”, in The Strains of Economic Growth: Labor Unrest and Social Dissatisfaction in Korea. Lindaeur et al., eds. Cambridge: HarvardUniversity Press.

Walder, Andrew. 1986. Communist Neo-Traditionalism; Work and Authority in Chinese Industry. Berkeley: University of California Press.

Wall Street Journal. 2/11/98. "Korean Unions Step Up Fight on Layoffs".

Warner, Malcolm. June 1987. "Industial Relations in the Chinese Factory”. The Journal of Industrial Relations. Volume 29 Number 2.

Wedley, Nigel, ed. 1992. Changes in the Iron Rice Bowl: The Reformation of Chinese Management. Greenwich: Jai Press.

White, Gordon. September 1987. "The Politics of Economic Reform in Chinese Industry: The Introduction of the Labor Contract System”. The China Quarterly.

White, L.T. 1989. "Shanghai Shanghaied? Uneven Taxes in Reform China", occasional paper no. 84. Hong Kong: Centre of Asian Studies, University of Hong Kong

Yoo, Gyeongjoon. 1995. An Analysis and Decomposition of Changing Labor Income Distribution in Korea, Dissertation for Cornell University. 
